\title{
The Antioxidant potential of ethanolic extract of edible mushroom Lycoperdon molle Pers. (Agaricomycetes)
}

\author{
Celal BAL ${ }^{1, *}$, Hasan AKGÜL ${ }^{2}$, Mustafa SEVİNDİK ${ }^{3}$ \\ 1,* Oguzeli Vocational School, University of Gaziantep 27910 Gaziantep, Turkey \\ ${ }^{2}$ Department of Biology, Faculty of Science, University of Akdeniz 07070 Antalya, Turkey \\ ${ }^{3}$ Department of Food Processing, Bahçe Vocational School, Osmaniye Korkut Ata University, \\ Osmaniye, Turkey 80500 \\ Corresponding author: bal@gantep.edu.tr
}

\begin{abstract}
Mushroom play an important role in the decay of organic cover in forest ecosystems. In addition, mushrooms which are forest products are consumed as food. This study aims to determine the antioxidant activity of ethanol (EtOH) extract from edible Lycoperdon molle Pers. mushroom collected from Antalya (Turkey). Total antioxidant status (TAS), total oxidant status (TOS) and the oxidative stress index (OSI) were analyzed using Rel Assay Diagnostics kits. In addition, free radical scavenging activity was determined using the DPPH method. As a result of the studies, TAS, TOS and OSI values of L. molle were $1.855 \pm 0.072,2.201 \pm 0.085$ and $0.119 \pm 0.008$, respectively. The free radical scavenging activity of the fungus was at a normal level in comparison to the standards used, i.e. rosmarinic and caffeic acids. Consequently, it was determined that $L$. molle may be used as a source of natural antioxidants. As a result, it was determined that edible $L$. molle, which is one of the forest products, has antioxidant potential in addition to its nutritional properties.
\end{abstract}

Keywords: Lycoperdon molle, Antioxidant, Oxidant, DPPH, Oxidative stress.

Özet

Mantarlar orman ekosistemlerinde organic örtünün ayrıștırılmasında önemli rol oynarlar. Ayrıca orman ürünleri olan mantarlar gida olarak tüketilmektedir Bu çalışmada Antalya (Turkey) ilinden toplanan yenilebilir Lycoperdon molle Pers. mantarının etanol (EtOH) ekstraktının antioksidan aktivitesinin belirlenmesi amaçlanmıştır. Mantar örneklerinin soxhlet cihazında özütleme işlemi yapılmıştır. Toplam antioksidan aktivitesi, toplam oksidan aktivitesi ve oksidatif stress indeksi Rel Assay Diagnostics kitleri kullanılarak analiz belirlenmiştir. Ayrıca serbest radikal süpürme aktivitesi DPPH metodu kullanılarak belirlenmiştir. Yapılan çalışmalar sonucunda L. molle'nin TAS değeri $1.855 \pm 0.072$, TOS değeri $2.201 \pm 0.085$ ve OSI değeri ise $0.119 \pm 0.008$ olarak belirlenmiştir. Mantarın serbest radikal süpürme aktivitesinin ise kullanılan standartlar rosmarinik asit ve caffeic asite göre normal seviyelerde olduğu belirlenmiştir. Sonuç olarak L. molle'nin doğal antioksidan olarak kullanılabileceği belirlenmiştir. Sonuç olarak orman ürünlerinden olan yenilebilir L. molle'nin besin özelliklerine ek olarak antioksidan potansiyelinin olduğu belirlenmiştir.

Keywords: Lycoperdon molle, Antioxidant, Oxidant, DPPH, Oxidative stres.

\section{Introduction}

Mushrooms exhibit cosmopolitan distribution. Macrofungi belong to the order of Basidiomycetes or Ascomycetes and they can be found in soils rich in organic matter and 
humus as well as various substrates such as in moist wood. Moreover, they can be found in animal dung after heavy rain or anywhere after sudden temperature changes occur and they then disappear after a short time, i.e. within several hours or at the end of the day (Girma and Tasisa 2018). The number of macrofungi species in nature is estimated to be between 53 and 110 thousand globally, however only a few are considered as nutrients and are able to be cultivated commercially (Mueller et al. 2007). Edible mushrooms have been globally consumed with increasing popularity due to their nutritional and medicinal value since Ancient Greek and Roman times (Udu-Ibiam et al. 2014). The fruiting bodies of fungi are consumed due to their variant textures and tastes. In addition, they are considerably important sources of dietary fiber, minerals, vitamins, water, proteins and carbohydrates (Kalac 2012, Y1lmaz et al. 2016, Durmaz et al. 2018).

It has been found that mushrooms also have various pharmacological properties in addition to their nutritional value. Previous studies have reported that mushrooms had antioxidant, antimicrobial, anticancer, antiproliferative, DNA-protective, antiallergic, analgesic, antitumor, immunosuppressive, antiatherogenic, hypoglycemic, anti-inflammatory, hepatoprotective activities (Yang et al. 2008, Hetland et al. 2011, Patel and Goyal 2012, Ren et al. 2012, Li et al. 2013, Soares et al. 2013, Sun et al. 2014, Elsayed et al. 2014, Y1ld1z et al. 2015, Bal et al. 2017, Béni et al. 2018). Also, it has been found that Lycoperdon sp. mushrooms also have various pharmacological properties, in addition to their nutritional value. Previous studies have reported that mushrooms have antioxidant, antimicrobial, antiproliferative, antitumor, immunosuppressive and esterolytic activity (Colak et al. 2009, Shen et al. 2009, Sing et al. 2012, Novaković et al. 2015, Akpi et al. 2017).

Mushrooms are very valuable forest products. They are distributed in different forest ecosystems as saprotrophic, pathogenic and parasitic (Akata et al., 2018). In this context, they produce different levels of antioxidant and oxidant compounds depending on their habitats and capacities (Bal et al., 2019). In this study L. molle which is an edible species was used as material. In addition to the edible properties of the fungus, it was aimed to determine the presence of antioxidant potential. In addition, the oxidant level of the fungus was determined and the condition of the region where it was collected in terms of oxidant compound was determined.

In this context, this study aims to determine the antioxidant potential of the L. molle, an edible mushroom.

\section{Material and Method}

\section{Mushroom Samples and Ethanolic Extract Preparation}

L. molle were collected in Elmal1/Antalya, Turkey in 2018. Mushroom samples were collected from pine forest. Mushroom samples were introduced into the laboratory environment under suitable conditions. After identification of the mushroom samples, ethanol (EtOH) extraction of the mushrooms was carried out at 500C for nearly 6 hours using a Soxhlet extractor (Gerhardt EV 14). The extracts were concentrated using a rotary evaporator (Heidolph Laborota 4000 Rotary Evaporator).

\section{TAS, TOS and OSI tests}


The total antioxidant status (TAS) and total oxidant status (TOS) of the mushrooms were determined using Rel Assay kits (Rel Assay Diagnostics Kits, Turkey). Trolox was used as a calibrator in determining the TAS value and the results were expressed in mmol Trolox equiv./L (Erel 2004). Hydrogen peroxide was used as a calibrator in determining the TOS value and the results were expressed in $\mu \mathrm{mol} \mathrm{H}_{2} \mathrm{O}_{2}$ equiv./L (Erel 2005). OSI values were calculated by dividing the obtained TOS value by the obtained TAS value. OSI (arbitrary unit: AU) was calculated according to the following formula and expressed in percentage terms (Erel 2005).

$$
\text { OSI }=\frac{\text { TOS, } \mu \mathrm{mol} \mathrm{H}_{2} \mathrm{O}_{2} \text { equiv./L }}{\text { TAS, mmol Trolox equiv./L X } 10}
$$

In this current study, six mushroom samples were obtained from the mushrooms and the measurements were repeated five times.

\section{DPPH Free Radical Scavenging Activity Assay}

The free radical scavenging activity of the mushrooms was determined using 1-diphenyl-2picrylhydrazyl (DPPH). Stock solutions containing $1 \mathrm{mg} / \mathrm{mL}$ extract were prepared with DMSO. $50 \mu \mathrm{L}$ solution was added to $160 \mu \mathrm{L} 0.039 \%$ DPPH. The resulting solution was incubated in the dark at room temperature for 30 minutes. A reading for absorbance at $517 \mathrm{~nm}$ was obtained. The procedures were repeated individually for each concentration and sample (Shimada et al. 1992). In addition, caffeic and rosmarinic acids were used as reference antioxidants. Then, DPPH free radical scavenging percentages were calculated according to the formula:

Scavenging activity $(\%)=[($ ADPPH-ASample $) /($ ADPPH $)] x 100$.

\section{Results and Discussion}

Antioxidant activity

In addition to the benefits of oxygen for biological systems, it can also have side effects that are potentially harmful. Reactivity allows oxygen to take part in high-energy electron transfers and, therefore, supports a high amount of adenosine-5-triphosphate (ATP) formation via oxidative phosphorylation. Hence, it plays an important role in the development of multicellular organisms. Despite the benefits, oxygen also has the potential to harm many biological molecules such as proteins, lipids and DNA. Consequently, living organisms are always threatened by reactive oxygen species (ROS). This threat is generally balanced by the antioxidant protection system. However, this balance can be disrupted due to many environmental and inherent effects leading to oxidative stress (Burton and Jauniaux 2011; Sevindik et al., 2018).

The oxidative stress, which can manifest as a result of different environmental and inherent effects, is referred to as an imbalance between the production and elimination of reactive oxygen species (ROS) that cause multiple oxidative modifications of the basic and regulatory processes. Oxidative stress can increase due to increased levels of ROS, drug metabolism, overexpression of enzymes producing ROS or ionizing radiation as well as antioxidant enzyme deficiency (Gospodaryov and Lushchak 2012). Oxidative stress is associated with cellular 
aging, acute and chronic kidney disease, neurodegenerative diseases, macular degeneration, biliary diseases, cancer and various acute and chronic pathological processes in addition to cardiovascular risk factors (obesity, diabetes, hypertension and atherosclerosis) (Burton et al. 2010; Chandrasekaran et al. 2017, Liguori et al. 2018; Sevindik, 2018).

In synthesis, given the close relationship between oxidative stress, inflammation, and aging, the oxidation-inflammatory theory of aging or oxi-inflamm-aging has been proposed: aging is a loss of homeostasis due to chronic oxidative stress that affects especially the regulatory systems, such as the nervous, endocrine, and immune systems. The consequent activation of the immune system induces an inflammatory state that creates a vicious circle in which chronic oxidative stress and inflammation feed each other and consequently, increases the age-related morbidity and mortality (De la Fuente and Miquel 2009, Liguori et al. 2018). Living organisms developed antioxidant defense systems in order to protect themselves from the negative effects of oxidative stress. These systems include some antioxidants produced in the body (endogenous) and some antioxidants derived from the diet (exogenous) (Rahman et al. 2012). It is of utmost importance to take antioxidant supplements in order to reduce oxidative stress when endogenous antioxidants are insufficient.

In this study, the antioxidant capacity of an edible mushroom, L. molle, was investigated. As a result, TAS, TOS and OSI values of $L$. molle were determined to be $1.855 \pm 0.072 \mathrm{mmol} / \mathrm{L}$, $2.201 \pm 0.085 \mu \mathrm{mol} / \mathrm{L}$ and $0.119 \pm 0.008$, respectively. There is no previous study investigating the oxidative stress status of $L$. molle. According to previous studies, the TAS values of other medicinal mushrooms, such as Auricularia auricula and Trametes versicolor were found to be 1.010 and $0.820 \mathrm{mmol} / \mathrm{L}$, TOS values of the same species were found to be 23.910 and 17.760 $\mu \mathrm{mol} / \mathrm{L}$, whereby OSI values 2.367 and 2.166, respectively (Akgül et al. 2017). Moreover, TAS, TOS and OSI values for Fomitopsis pinicola were reported to be 1.44, 14.21 and 0.99 , respectively (Sevindik et al. 2017). In comparison to these studies, L. molle was found to have a higher TAS value compared to A. auricula, T. versicolor and $F$. pinicola . Moreover, L. molle had lower TOS and OSI values compared to A. auricula, T. versicolor and F. pinicola species. It is thought that the differences in TAS, TOS and OSI values stem from the antioxidant production capacity, oxidant production capacity and environmental conditions of habitat of the fungus, as well as from their substrate.

Table1. DPPH scavenging activity of L. molle

\begin{tabular}{lllll}
\hline \multicolumn{5}{c}{ Mushroom extract concentrations } \\
\hline & $0.25 \mathrm{mg} / \mathrm{mL}$ & $0.5 \mathrm{mg} / \mathrm{mL}$ & $1 \mathrm{mg} / \mathrm{mL}$ & $2 \mathrm{mg} / \mathrm{mL}$ \\
\hline Caffeic acid & $8.62 \pm 0.91$ & $21.34 \pm 0.66$ & $38.39 \pm 0.66$ & $59.47 \pm 0.05$ \\
Rosmarinic acid & $6.03 \pm 0.15$ & $7.00 \pm 0.41$ & $35.09 \pm 0.10$ & $61.91 \pm 8.77$ \\
L. molle & $25.15 \pm 1.86$ & $34.48 \pm 3.75$ & $43.05 \pm 1.27$ & $51.72 \pm 3.25$ \\
\hline
\end{tabular}

In addition, it was found that the DPPH activity of L. mole's fruiting bodies extract at $0.25,0.5$, 1 and $2 \mathrm{mg} / \mathrm{mL}$ concentrations ranged between $25.15 \%$ and $51.72 \%$ (Table 1). Caffeic and rosmarinic acids as standards displayed $59.47 \pm 0.05 \%$ and $61.91 \pm 8.77 \%$ activity, respectively at a $2 \mathrm{mg} / \mathrm{mL}$ extract concentration. It was observed that the crude extract of the L. molle fruiting bodies exhibited activity similar to the standards used. Previous studies have reported that 
methanol, ethanol and acetone extracts of $L$. molle displayed high DPPH free radical scavenging activity (Barros et al. 2008, Singh et al. 2012). This current study also indicated that L. molle's fruiting bodies extract possesses DPPH free radical scavenging activity which has demonstrated the antioxidant potential of the studied fungus.

Wild edible and medicinal mushrooms represent important forest products world-wide (Bonet et al., 2008; Bal et al., 2019). The material used in our study, L. molle is quite common and edible mushroom According to the results of the study, L. molle has antioxidant potential. Mushrooms, which are among forest products, are very important in determining new antioxidant sources. In this study, it was determined that $L$. molle has an important place in the forest ecosystem.

\section{Conclusion}

In this study, the antioxidant status of the edible mushroom $L$. molle was determined. This fungus displayed a high TAS value and a good DPPH free radical scavenging activity. L. molle may be a source of antioxidant compounds. Mushrooms are not only a source of income for collectors and tourism businesses, but can also provide economic incentives for forest owners. Therefore, it can improve forest management.

\section{References}

Akata, I., Kabaktepe, Ş., Sevindik, M., Akgül, H. (2018). Macrofungi determined in Yuvacık Basin (Kocaeli) and its close environs. Kastamonu Üniversitesi Orman Fakültesi Dergisi, 18(2): 152-163.

Akgul, H., Sevindik, M., Coban, C., Alli, H., Selamoglu, Z. (2017). New Approaches in Traditional and Complementary Alternative Medicine Practices: Auricularia auricula and Trametes versicolor. J Tradit Med Clin Natur. 6(2): 239

Akpi, U.K., Odoh, C.K., Ideh, E.E., Adobu, U.S. (2017). Antimicrobial activity of Lycoperdon perlatum whole fruit body on common pathogenic bacteria and fungi. African Journal of Clinical and Experimental Microbiology, 18(2): 79-85.

Bal, C., Akgul, H., Sevindik, M., Akata, I., Yumrutas, O. (2017). Determination of the anti-oxidative activities of six mushrooms. Fresenius Envir Bull., 26(10): 6246-6252.

Bal, C., Sevindik, M., Akgul, H., Selamoglu, Z. (2019). Oxidative Stress Index and Antioxidant Capacity of Lepista nuda Collected From Gaziantep/Turkey. Sigma, 37(1): 1-5.

Barros, L, Venturini, B.A., Baptista, P., Estevinho, L.M., Ferreira, I.C. (2008). Chemical composition and biological properties of Portuguese wild mushrooms: a comprehensive study. Journal of agricultural and food chemistry, 56(10): 3856-3862.

Béni, Z., Dékány, M., Kovács, B., Csupor-Löffler, B., Zomborszki, Z., Kerekes, E., Szekeres, A., Urbán, E., Hohmann, J., Ványolós, A. (2018). Bioactivity-guided isolation of antimicrobial and antioxidant metabolites from the mushroom Tapinella atrotomentosa. Molecules, 23(5): 1082.

Bonet, J. A., Pukkala, T., Fischer, C. R., Palahí, M., de Aragón, J. M., Colinas, C. (2008). Empirical models for predicting the production of wild mushrooms in Scots pine (Pinus sylvestris L.) forests in the Central Pyrenees. Annals of Forest Science, 65(2): 1.

Burton, D.G.A., Matsubara, H., Ikeda, K. (2010). Pathophysiology of vascular calcification: Pivotal role of cellular senescence in vascular smooth muscle cells. Experimental gerontology, 45(11): 819-824.

Burton, G.J., Jauniaux, E. (2011). Oxidative stress. Best practice \& research Clinical obstetrics \& gynaecology, 25(3): 287-299. 
Chandrasekaran, A., Idelchik, M.D.P.S., Melendez, J.A. (2017). Redox control of senescence and agerelated disease. Redox biology, 11: 91-102.

Colak, A., Camedan, Y., Faiz, O., Sesli, E., Kolcuoğlu, Y. (2009). An esterolytic activity from a wild edible mushroom, Lycoperdon perlatum. Journal of food biochemistry, 33(4): 482-499.

De la Fuente, M., Miquel, J. (2009). An update of the oxidation-inflammation theory of aging: the involvement of the immune system in oxi-inflamm-aging. Current pharmaceutical design, 15(26), 3003.

Durmaz, F., Sezer, E.N.Ş., Aktaş, S. (2018). Yenilebilir bir tür olan Lycoperdon utriformis Bull.'in yağ asit kompozisyonlarının gaz kromatoğrafisi (GC)'de tayin edilmesi. Mantar Dergisi, 9(1): 50-53

Elsayed, E.A., El Enshasy, H., Wadaan, M.A., Aziz, R. (2014). Mushrooms: a potential natural source of anti-inflammatory compounds for medical applications. Mediators of inflammation 2014. doi: $10.1155 / 2014 / 805841$

Erel, O. (2004). A novel automated direct measurement method for total antioxidant capacity using a new generation, more stable ABTS radical cation. Clinical biochemistry, 37(4): 277- 285.

Erel, O. (2005). A new automated colorimetric method for measuring total oxidant status. Clinical biochemistry, 38(12): 1103-1111.

Girma, W., Tasisa, T. (2018). Application of Mushroom as Food and Medicine. Adv Biotech \& Micro, 11(4): 555817.

Gospodaryov, D., Lushchak, V. (2012). Oxidative Stress: cause and consequence of diseases. In Oxidative stress and diseases. IntechOpen.

Hetland, G., Johnson, E., Lyberg, T., Kvalheim, G. (2011). The mushroom Agaricus blazei Murill elicits medicinal effects on tumor, infection, allergy, and inflammation through its modulation of innate immunity and amelioration of $\mathrm{Th} 1 / \mathrm{Th} 2$ imbalance and inflammation. Advances in pharmacological sciences, 2011: doi: 10.1155/2011/157015

Kalac, P. (2012). Chemical composition and nutritional value of European species of wild growing mushrooms. W: Mushrooms: Types, Properties and Nutrition. Andres S., Bauman (red.), N. Nova Science Pub. Inc., New York, 129-152.

Li, Y., Bao, L., Song, B., Han, J., Li, H., Zhao, F., Liu, H. (2013). A new benzoquinone and a new benzofuran from the edible mushroom Neolentinus lepideus and their inhibitory activity in NO production inhibition assay. Food chemistry, 141(3): 1614-1618.

Liguori, I., Russo, G., Curcio, F., Bulli, G., Aran, L., Della-Morte, D., Gargiulo, G., Testa, G., Cacciatore, F., Bonaduce, D., Abete, P. (2018). Oxidative stress, aging, and diseases. Clinical interventions in aging, 13: 757 .

Mueller, G.M., Schmit, J.P., Leacock, P.R., Buyck, B., Cifuentes, J., Desjardin, D.E., Halling, R.E., Hjortstam, K., Iturriaga, T., Larsson, K.H., Lodge, D.J., May, T.W., Minter, D., Rajchenberg, M., Redhead, S.A., Ryvarden, L., Trappe, J.M., Watling, R., Wu, Q. (2007). Global diversity and distribution of macrofungi. Biodiversity and conservation, 16(1): 37-48

Novaković, A.R., Karaman, M.A., Matavulj, M.N., Pejin, B.M., Belović, M.M., Radusin, T.I., Ilić, N.M. (2015). An insight into in vitro bioactivity of wild-growing puffball species Lycoperdon perlatum (Pers) 1796. Food and Feed Research, 42(1): 51-58.

Patel, S., Goyal, A. (2012). Recent developments in mushrooms as anti-cancer therapeutics: a review. 3 Biotech, 2(1): 1-15.

Rahman, T., Hosen, I., Islam, M.T., Shekhar, H.U. (2012). Oxidative stress and human health. Advances in Bioscience and Biotechnology, 3(07): 997. 
Ren, L., Perera, C., Hemar, Y. (2012). Antitumor activity of mushroom polysaccharides: a review. Food \& Function, 3(11): 1118-1130.

Sevindik, M., Akgul, H., Akata, I., Alli, H., Selamoglu, Z. (2017). Fomitopsis pinicola in healthful dietary approach and their therapeutic potentials. Acta Alimentaria, 46(4): 464-469.

Sevindik, M., Akgul, H., Bal, C., Altuntas, D., Korkmaz, A. I., Dogan, M. (2018). Oxidative Stress and Heavy Metal Levels of Pholiota limonella Mushroom Collected from Different Regions. Current Chemical Biology, 12(2): 169-172.

Sevindik, M. (2018). Antioxidant and antimicrobial activity of Cerrena unicolor. Mycopath, 16(1): 11-14

Shen, Q., Chen, W., Yan, Z., Xie, Z. (2009). Potential pharmaceutical resources of the Qinling Mountain in central China: medicinal fungi. Frontiers of Biology in China, 4(1): 89-93.

Shimada, K., Fujikawa, K., Yahara, K., Nakamura, T. (1992). Antioxidative properties of xanthan on the autoxidation of soybean oil in cyclodextrin emulsion. Journal of agricultural and food chemistry, 40(6): 945-948.

Singh, P., Singh, A., D'Souza, L., Roy, U., Singh, S. (2012). Chemical constituents and antioxidant activity of the Arctic mushroom Lycoperdon molle Pers. Polar Research, 31(1): 17329.

Soares, A., de Sá-Nakanishi, A., Bracht, A., da Costa, S., Koehnlein, E., de Souza, C., Peralta, R. (2013). Hepatoprotective effects of mushrooms. Molecules, 18(7): 7609-7630.

Sun, J., Ng, T.B., Wang, H., Zhang, G. (2014). A novel hemagglutinin with antiproliferative activity against tumor cells from the hallucinogenic mushroom Boletus speciosus. BioMed research international, 2014: doi: $10.1155 / 2014 / 340467$

Udu-Ibiam, O.E., Ogbu, O., Ibiam, U.A., Nnachi, A.U., Agah, M.V., Ukaegbu, C.O., Chukwu, O.S., Agumah, N.B., Ogbu, K.I. (2014). Phytochemical and antioxidant analyses of selected edible mushrooms, ginger and garlic from Ebonyi State, Nigeria. IOSR Journal of Pharmacy and Biological Sciences, 9(3): 86-91.

Yang BK, Kim GN, Jeong YT, Jeong H, Mehta P, Song CH (2008) Hypoglycemic effects of exobiopolymers produced by five different medicinal mushrooms in STZ-induced diabetic rats. Mycobiology, 36(1): 45-49.

Yıldız, S., Yılmaz, A., Can, Z., Tabbouche, S.A., Kılıç, A.O., Sesli, E. (2015). Some Bioactive Propertıes of Wild And Commercial Mushroom Species. Journal of Food and Health Science, 3(4): 161-169.

Yılmaz, A., Yıldız, S., Kılı̧̧, C., Can, Z. (2016). Total phenolics, flavonoids, tannin contents and antioxidant properties of Pleurotus ostreatus cultivated on different wastes and sawdust. International Journal of Secondary Metabolite, 4(1): 1-9.

Submitted: 13-07-2019 Accepted: 22-10-2019 